Asian Review of Social Sciences

ISSN: 2249-6319 Vol. 9 No.1, pp. 34-38

(C) The Research Publication, www.trp.org.in

\title{
Participatory Exclusion in Water User Associations: A Subaltern Perspective
}

\author{
K. Gulam Dasthagir \\ Project Director, ICSSR Major Research Project, Department of Sociology, \\ School of Social Sciences and International Studies, Pondicherry University, Puducherry \\ E-mail: dasthagir@gmail.com
}

\begin{abstract}
Although Participatory Irrigation Management envisions democratic participation and equity in water sharing among farmers, this article while investigating the challenges of Dalit farmers in Water User Associations and access to surface or ground water for irrigation, espouse the perpetuation of 'Participatory Exclusion' of Dalit farmers in canal water sharing and rights in water user associations . Since caste discrimination is embedded in modern user organizations, participatory exclusion of Dalit farmers operates at all levels of membership, participation and representation in PIMinrural Tamil Nadu.

Keywords: Participatory Exclusion, Dalit Farmers, Participatory Irrigation Management, Water User Associations, Sathanur Major Irrigation System.
\end{abstract}

\section{INTRODUCTION}

A prominent feature of irrigation development in the 21st century is crafting legislative regime of Participatory Irrigation Management (PIM) enunciated through the enactment of legal paradigm according pre-eminence for enhanced participation of water users both women and men in the management and operation of the major and medium irrigation systems (Pant, 2008). Conversely, the context of Indian rural society in which PIM has to operate is permeated by caste discrimination and social exclusion. Indeed, hierarchy appears as the single most important idea in the Indian culture that pervaded almost every aspect of village life (Appadurai, 1988). The predominant interface of caste and class continue to determine the agrarian social structure and access to irrigation water.

Subaltern 'refers to the perspective from below', a view from the bottom of society or the flow of knowledge from below. Since agriculture is the major employer of rural Dalit, all their privations cumulate in the context of irrigation water management. Against the backdrop of perpetuation of caste discrimination in rural India, This research endeavors to inquire into the nature of inclusion and exclusion experienced by Dalit farmers in canal water sharing and participation in WUAs.

\section{PARTICIPATORY EXCLUSION IN WATER USER ASSOCIATIONS}

With The establishment of PIM, it is assumed that WUAs are responsible for representing communities in managing water structures and decision-making at the local scale
(Hoojah, Rakesh, 2006)as these neoliberal institutions are premised on inclusiveness and effective participation and people's involvement as a collectivity for devolving greater power for institutionalizing participative development.

In fact, Irrigation Management Transfer is based on the postulation that organizations of landowners, delineated by hydrological boundary, are inclusive and take care of fair distribution of water (Gulati et al, 2005. Contradictorily, the hydraulic basis of user organization is not an undifferentiated social entity. In tandem, discrimination based on class, caste, gender and other social differences persist within WUAs (Kulkarni, 2011).

Further, within hydrologically delineated user groups, access to and control over water resources vary by multiple, interlocking and hierarchical systems of differentiation (Agarwal, 2001). Even though these user groups are formed to operate on principles of cooperation by involving and benefiting all sections of the community, they are likely to effectively exclude significant sections such as Dalits.

Several studies across Indian Territory argued that social structure caste-class hierarchy is decisive to water use and management as at the local level (Appadurai 1988). In addition, hierarchical arrangement creates barriers to equitable distribution of benefits of irrigation development to Dalit Such structured inequalities segregate the Dalit to occupy the low status in society in which caste/class discrimination and injustices permeated to lower the socioeconomic status of rural Dalit families. Consequently, their access to rights, public participation and representation are impervious challenge to enunciation of participatory governance, inclusive democracy and human justice in India. Correspondingly, in the context of irrigation in most part of India, large and middle farmers are found to have better access to irrigation (Pant, 2005; Shah, 1993). Moreover, unequal caste, class and power relations have aggravated canal water scarcity (Prakash\&Sama, 2006).Since all rights to use water are gained through ownership of land and in most parts of South Asia Dalit do not own land, their enrolment in WUAs is minimal as membership is contingent upon landownership (ADB, 2008).

Agarwal (2001) argues that participatory institutions implicitly foster "participatory exclusions" i.e. exclusions 
within user organizations, emanating from systemic factors with adverse consequences to both equity and institutional efficiency. Agarwal (2001) argues that these seemingly participatory institutions implicitly foster 'participatory exclusions', that is, exclusions within user organizations, emanating from systemic factors with adverse consequences to both equity and institutional efficiency. She argues that participation determined by rules, norms and perceptions of these participatory institutions, in addition to the endowments and attributes of participants, can disadvantage Dalit. Agarwal (2001) conceptualized participation in user groups with a range of levels, namely

1. Nominal participation- Membership in the group,

2. Consultative participation-being passive observer or informed of decisions,

3. Activity-specific participation-performing specified tasks,

4. Active participation-expressing opinions and taking initiatives and

5. Interactive (empowering) participation-having voice and influence in the group's decisions.

Agarwalpropounded that achieving effective participation would involve a shift from lower to higher level indicating the extent of users' activeness. In this formulation, dalit being absent or just nominal inclusion but not interactive (empowered) participantsdenote participatory exclusion. Correspondingly, In the backdrop of historicity of social exclusion centered around the caste structure of Indian society, the idea of people's participation in the management of local water resources by rural user groups deserve a subaltern analysis.

\section{PARTICIPATORY IRRIGATION MANAGEMENT IN TAMIL NADU}

PIM was introduced in Tamil Nadu through World Bank funding, with the imperative to adopt Irrigation Management Transfer (IMT) (Elumalai, 2000). The Government of Tamil Nadu accepted the concept of PIM from World Bank in order to facilitate farmers' participation in the operation, management and maintenance of the irrigation water distribution systems, maintained by the Water Resource Organization of PWD. Concomitantly, institutional reforms were initiated with the adoption of Water Policy (1994), execution of Water Resources Consolidation Project (TNWRCP 1995-2004) (Elumalai, 2000).

Accordingly, Tamil Nadu Farmers' Management of Irrigation Systems (TNFMIS) Act was enacted in 2000 Rules to the act 2002 and Election rules 2003 were also framed and notified by the Government. According to TNFMIS Act, Farmer Organizations have to be given the effective role in management and maintenance of the irrigation system for effective and reliable supply and distribution of water for agriculture (Govt. Tamil Nadu, 2000). The Farmer Organizations are designed to have three tier structure (ADB, 2008) including Water User Associations (WUAs) at the primary system level, Distributary Committees at the secondary system level and Project Committees at the main system level (Water Resource Organization records).

\section{METHODOLOGY}

Participation of Dalit Farmers in irrigation management was explored through qualitative data gathered from Focus group discussions (FGD).For this purpose, Villupuram District with large proportion of Dalit in Tamil Nadu was selected based on demographic data from Census report. Within this district, WUAs with greater number of Dalit landowners was identified through discussions with informants and based on WUA records.

Thus, Aarur WUA with large number of Dalit farmers covering Varagur, Thimmananthal, Kidangudaiyampattu villages is studied. There were 44 Dalit members of WUAs, of which 16 participated in the FGD. The farmers gathered at the residence of the T.C member of Varagur village who is also a Dalit. Thus organizing FGD was made possible due to the support of the Dalit leaders and a venue of meeting in a Dalit congenial atmosphere. Dalit farmers responded to the meetings with greater enthusiasm as they reported that were invited for meetings regarding irrigated agriculture for the first time.

\section{PARTICIPATORY EXCLUSION OF DALIT FARMERS IN CANAL IRRIGATION}

During FGD, Dalit farmers expressed that they are recognized as land owners and water users through this meeting. Nonetheless, despite belonging to the same category of Dalit farmers, they were found to share certain commonalities as well as differences in terms of size of land holding participation in irrigation and cultivation source of irrigation and the like.

\section{MARGINALIZATION}

The most striking commonality is that though their land holdings range between 0.20 cents to 1.5 acres, the Dalit farmers own less than 1 hectare and are marginal in terms of land ownership. They are not only backward in terms of caste but also backward in terms of agriculture land holdings. Another commonality of this farmers is that their land holdings not only tiny but also located at the tail ends of the canal system. In fact the Aarur WUA itself is a tail end WUA. In other associations none of the participant owned lands in the head or middle end. Thus these farmers are marginal as well as marginalized in terms of the location of their land in irrigation system. Being marginalized in the command area of the irrigation system, these women reported to supply of water for irrigation. The responses of the farmers participated in the FGD are quantified in the table given below. 


\section{HYDRAULIC EXCLUSION}

It emerged from the FGD that Dalit farmers rely upon ground water or rain water or purchase water for irrigation. This evidence establishes that the Dalit farmers do not receive canal water despite their ownership of their lands in the command area of the major irrigation system. Therefore, the discussion was focused to probe into the reasons for non-availability of canal water to their land.

\section{TABLE I PARTICIPATORY EXCLUSION IN RELATION TO SOURCE OF IRRIGATION}

\begin{tabular}{|c|c|c|c|}
\hline \multirow{2}{*}{$\begin{array}{l}\text { Source of } \\
\text { Irrigation }\end{array}$} & \multicolumn{3}{|c|}{ Gender Composition of Farmers } \\
\hline & Male & Female & Total \\
\hline $\begin{array}{l}\text { Canal } \\
\text { water }\end{array}$ & $\begin{array}{c}1(100 \%) \\
{[8.3 \%]}\end{array}$ & - & $\begin{array}{c}1(100 \%) \\
{[6.2 \%]}\end{array}$ \\
\hline $\begin{array}{l}\text { Energised } \\
\text { water }\end{array}$ & $\begin{array}{c}2(66.7 \%) \\
{[16.7 \%]} \\
\end{array}$ & $\begin{array}{c}1(33.3 \%) \\
{[25.0 \%]}\end{array}$ & $\begin{array}{l}3(100 \%) \\
{[18.8 \%]}\end{array}$ \\
\hline $\begin{array}{l}\text { Rain } \\
\text { water }\end{array}$ & $\begin{array}{c}4(80.0 \%) \\
{[33.3 \%]}\end{array}$ & $\begin{array}{c}1(20.0 \%) \\
{[25.0 \%]}\end{array}$ & $\begin{array}{l}5(100 \%) \\
{[31.2 \%]}\end{array}$ \\
\hline $\begin{array}{l}\text { Hired } \\
\text { water }\end{array}$ & $\begin{array}{l}3(100 \%) \\
{[25.0 \%]}\end{array}$ & $\begin{array}{c}0(0 \%) \\
{[0 \%]}\end{array}$ & $\begin{array}{c}(100 \%) \\
{[18.8]} \\
\end{array}$ \\
\hline $\begin{array}{l}\text { Non } \\
\text { cultivation }\end{array}$ & $\begin{array}{c}2(50.0 \%) \\
{[16.7 \%]}\end{array}$ & $\begin{array}{c}2(50.0 \%) \\
{[50.0 \%]}\end{array}$ & $\begin{array}{l}4(100 \%) \\
{[25.0 \%]}\end{array}$ \\
\hline Total & $\begin{array}{c}12(75.0 \%) \\
{[100 \%]}\end{array}$ & $\begin{array}{c}4((25.0 \%) \\
{[100 \%]}\end{array}$ & $\begin{array}{c}16(100 \%) \\
{[100 \%]}\end{array}$ \\
\hline
\end{tabular}

The participants expressed that the farmers in the head end and middle ends of the canal divert water to their fields that does not allow the possibilities of canal water flowing to the tail end lands. Further discussion revealed that middle end and head end farmers belong to upper castes who would like to receive water first and irrigate their fields entirely with canal water. Upper caste farmers also gain advantage from bureaucratic neglect of canal maintenance that facilitates over irrigation at head and middle reaches. Consequently the tail-enders who happened to be Dalit had to go without canal water. Moreover, damages to the irrigation channels and water control structures obviate the possibility of canal water reaching their lands. Therefore Dalit farmers rely on alternative sources of water for irrigation. Some participants disclosed about their dependence on rainfall for cultivating crops for a season. The cultivation is confined to dry crops and there to the rainy season. Thus in these case Dalit farmers are deprived of their income from their land due to absence of canal water supply

\section{WATER HIRING}

The table examines the impact of irrigation water supply on the participation of Dalit farmers in irrigated agriculture. Among the Dalitl and owners there are differences in terms of their participation in cultivation. It becomes apparent from the data that a majority of the farmers do not cultivate
The discussions brought to light the prevalence of a distinct practice of sale and purchase of irrigation water existing in this command area. A majority of the participants reported that they rely on hired water priced on hourly basis. These farmers informed that the farmers who have energized well (or) bore wells who own are in a position to extract ground water and selling to neighboring farmers for an informally prescribed price. The women added that due to this reason some of them are given up cultivation as agriculture has become a costly endeavor. Thus non availability of canal water and purchase of irrigation water has made the Dalit farmers land owners to give up cultivation as their livelihood. These findings establish that Dalit farmers are not only socially excluded, but also experience hydraulic exclusion being relegated to be tail Enders with marginal size of land holding and largely deprived of access to canal water. Besides, gender differences are found to accentuate deprivation in which women Dalit farmers are to a greater extent remain socially and economically depressed. Dalit farmers are not only socially depressed, but also hydrologically deprived, and consequently are deprived from PIM.

\section{LIVELIHOOD DEPRIVATION}

The nature of irrigation water source to a large extent affects the occupation of the Dalit farmers particularly their participation in cultivation of their own lands as depicted in the table below:

TABLE II PARTICIPATORY EXCLUSION IN RELATION TO PARTICIPATION IN IRRIGATED AGRICULTURE

\begin{tabular}{|c|c|c|c|}
\hline \multirow{2}{*}{$\begin{array}{l}\text { Nature of } \\
\text { livelihood }\end{array}$} & \multicolumn{3}{|c|}{$\begin{array}{c}\text { GENDER COMPOSITION OF } \\
\text { FARMERS }\end{array}$} \\
\hline & Male & Female & Total \\
\hline $\begin{array}{l}\text { Owner } \\
\text { Cultivator }\end{array}$ & $\begin{array}{c}1(100 \%) \\
{[8.3 \%]}\end{array}$ & $\begin{array}{c}0(0 \%) \\
{[0 \%]}\end{array}$ & $\begin{array}{c}1(100 \%) \\
{[6.1 \%]}\end{array}$ \\
\hline $\begin{array}{l}\text { Owner } \\
\text { cultivator } \\
\text { cum } \\
\text { laborer }\end{array}$ & $\begin{array}{c}2(75.00 \%) \\
{[16.7 \%]}\end{array}$ & $\begin{array}{c}1(25.00 \%) \\
{[25.0 \%]}\end{array}$ & $\begin{array}{l}3(100 \%) \\
{[18.8 \%]}\end{array}$ \\
\hline $\begin{array}{l}\text { Landed } \\
\text { agricultural } \\
\text { laborer }\end{array}$ & $\begin{array}{c}2(75.00 \%) \\
{[16.7 \%]}\end{array}$ & $\begin{array}{c}1(25.00 \%) \\
{[25.0 \%]}\end{array}$ & $\begin{array}{l}3(100 \%) \\
{[18.8 \%]}\end{array}$ \\
\hline $\begin{array}{l}\text { Non } \\
\text { cultivator }\end{array}$ & $\begin{array}{c}1(50.0 \%) \\
{[8.3 \%]}\end{array}$ & $\begin{array}{l}1(50.0 \%) \\
{[25.0 \%]}\end{array}$ & $\begin{array}{l}2(100 \%) \\
{[12.5 \%]}\end{array}$ \\
\hline $\begin{array}{l}\text { Non } \\
\text { cultivating } \\
\text { laborer }\end{array}$ & $\begin{array}{l}6(85.8 \%) \\
{[50.0 \%]}\end{array}$ & $\begin{array}{l}1(14.2 \%) \\
{[25.0 \%]}\end{array}$ & $\begin{array}{l}7(100 \%) \\
{[43.8 \%]}\end{array}$ \\
\hline Total & $\begin{array}{c}12(75.0 \%) \\
{[100 \%]}\end{array}$ & $\begin{array}{c}4(25.0 \%) \\
{[100 \%]}\end{array}$ & $\begin{array}{c}16(100 \%) \\
{[100 \%]}\end{array}$ \\
\hline
\end{tabular}

their lands. There are $(75.0 \%)$ of farmers who have belong to this category. Among them there are Non-Cultivators classified into:

1. Aged land owners lease out their lands or permit their male relatives to cultivate. 
2. Land owners who do not cultivate their lands but work as agricultural wage laborers in others fields.

3. Land owners who lease out of their land for cultivation and work for wages as labourers in others fields.

It is ironical that in the case of sizeable number of Dalit farmers lands situated in irrigation command area do not generate employment or income to Dalit in the absence of canal water supply. Thus, the ownership of agricultural land failed to empower Dalit in the absence of access to irrigation water.

\section{LANDED LABOURERS}

Paradoxically Dalit land owners even though are owners work as wage laborers in others agricultural fields. Thus, Dalit in spite of their participation in agriculture are deprived of their usufruct rights of their own lands and are pushed to the status of agricultural laborers. Literature narrates cases of landless agricultural laborers and land is a major employer in the context of rural society. Contradictorily in the case of Dalit farmer's ownership of land does not assure livelihood. Their title to land did not safeguard them from their traditional status of wage laborers. Thus, these Dalitfarmers can be termed as 'landed agricultural laborers'. Besides this category there are certain Dalit who also continue the traditional status of being agricultural laborers who, due to irrigational constraints handed over the lands for cultivation to others. In these cases, though their land is used for cultivation it does not provide them employment. Consequently these Dalit had to continue their traditional occupation of agricultural laborers. Therefore wage labour becomes their livelihood while their own land becomes additional income.

The latter category reveals the persistence of wage labour as the occupation of these Dalit farmers despite land ownership. These farmers take up cultivation of their land due to limited water supply, they cultivate for a season and in most part of the year they serve as wage laborer. The FGD's have made it amply clear that Dalit land owners are deprived of their right to irrigation water. In the absence of water supply they either denied of their livelihood from their own land or made to serve their male relatives or relegated to wage laborers. On a whole these evidences established that land reforms brought about a significant change in cutting across the boundaries of caste and gender inequality in the ownership of the land. Nonetheless a majority of cases land ownership has been to a large extent less instrumental in liberating Dalit from their traditional occupation of serving agricultural wage laborers, due to non-availability of irrigation water supply. Further land ownership has been to a greater extent less successful in overcoming in gender discrimination in agriculture. The arena of agriculture has landed Dalit women subjected to the male relatives for irrigation water supply to cultivate their lands. The FGD's have thrown light with empirical evidences towards the ongoing debate in gender theorizing and feminist literature that it is feasible for ownership of land by itself being a more powerful instrument of women empowerment. Property ownership necessarily ensure socio-economic independence of women in so far us the functionality and utilization of the property necessities the participation and power of the patriarchy.

\section{GENDER DISPARITY}

There are some Dalit women who rely on ground water energized well. They declared that these energized well are neither located in their land nor owned by energized wells by virtue of their male relatives they receive supply of water to their fields. Accordingly they carry on cultivation along with their male relatives and in most cases said to be assisting their husbands or brothers in cultivation and irrigation. Thus dependence on ground water in the absence of canal water subjugates the Dalit women to their male relatives (Dasthagir, 2016).There are some women cultivators who participate in the cultivation of their own land. Nonetheless, the discussions brought to light that these women rely on water supply from their male relatives, and thereby depend on them for organizing cultivation. They said that they assist their male relatives in agricultural activities. Thus the absence of independent water supply the women owner cultivators are subjected to male relatives.

\section{PARTICIPATORY EXCLUSION IN PARTICIPATORY IRRIGATION MANAGEMENT}

As per the records of the irrigation bureaucracy, all men and women landowners without choice are enrolled as participants in WUAs. Therefore, Dalit by virtue of law gain membership in WUAs without choice or selection. These Dalit farmers reported that they are unaware about the existence of WUA in their command area. They also informed their ignorance about the legislation, Conduct of elections, meetings, pertaining to management of irrigation system. Indeed they were not conscientised about their membership in WUA's. They have not been invited to any training programmes and meetings. Thus the Dalit farmers being uninformed about the meetings, trainings etc., have remained unaware of PIM. Consequently they do not realize their rights or benefits of this institutional reform. Thus the Dalitl and owners are excluded from the process of user participation.

Dalit farmers are numerically less preponderant and they constitute only a minority in WUAs. Moreover, they are systematically excluded from the process of institution building and are not conscientised about their rights in PIM. Thus, the inclusion of Dalit's in WUAs' record is rather 'notional'. Despite some Dalit by virtue of holding title to land are enlisted as members, their socio-economic, cultural predicaments impede their active participation in meetings, elections and decision-making in WUAs. In the elections of WUAs, Dalit farmers could neither exercise their voting rights nor contest in elections due to their unawareness. Accordingly, due to the hegemony of upper caste farmers under the banner of 'unanimous choice' Dalit farmers are not 
represented in committees and leadership of WUAs. A majority of Dalit, who are engaged in irrigated agriculture, are landless. These water users (a large proportion) actively participate in canal irrigation management without legal recognition of their rights and contributions. Consequently, landless Dalit are legally not recognized as members of PIM in the absence of landownership and thereby, are denied entry into WUAs.

Nevertheless, the participants expressed their grievances that they are levied land tax, water tax and chess without assured water delivery. Nonetheless, they express their willingness to participate in meetings and trainings in gaining knowledge about PIM in order to ameliorate their livelihood conditions. They appealed to the government bureaucracy to execute maintenance work in the canals and ensure water supply of canal water to all the registered water users including the tail end of the irrigation system. Meaningless without water, hence water supply can provide the incentive for land owners to take active part in WUA.

\section{CONCLUSION}

Institutional reforms and policy promulgations envisage, though implicitly, strategies for the inclusion of Dalit in participatory institutions, Dalit farmers continue to suffer due to marginal land holding lower social status, marginalized land location. Their dependence on their traditional occupations being wage laborer persists in the absence of reliable water supply to their agricultural lands owned by them. Thus land owned by Dalit without irrigation is dysfunctional in engendering livelihood to them and have disproved to be instruments of their empowerment.

Apart from various forms of caste discrimination made known by social scientists so far in Indian society, this investigation has brought to light the fact that supply of canal water and sharing or hiring/selling ground water is used as a source of upper caste domination to suppress the Dalit. Such hydraulic social exclusion hinging upon livelihood is to a greater extent perpetually oppressive to preclude Dalit women from participatory development. Moreover, delineation and apathy of bureaucratic canal irrigation systems preclude the participation of Dalit in PIM. Thus, participatory exclusion of Dalit farmers occurs at all levels of membership, participation and representation in PIM as nominal record-based membership of Dalit landowners systematically mitigates them from empowerment in PIM.

\section{ACKNOWLEDGEMENT}

This article is a part of the research project funded by Indian Council of Social Science Research (ICSSR, New Delhi), 2018-20.

\section{REFERENCES}

[1] Agarwal, B. (2001). Participatory exclusions, community forestry, and gender: An analysis for South Asia and a conceptual framework. World Development, 29, 1623-1648.

[2] Appadurai, Arjun. (1988). Putting hierarchy in its place: Place and voice in anthropological theory. Cultural Anthropology, 3 (1), 36-39.

[3] Asian Development Bank (ADB). (2008). Irrigation management transfer: Strategies and best and practices. New Delhi: SAGE.

[4] Dasthagir, K. G., (2016). Pani Panchayat for whom: Investigating preclusion of Dalit women in participatory irrigation institutions. Contemporary Voice of Dalit, 8 (2),163-176

[5] Elumalai. K.G., (2000). Introduction to strategies for implementation of PIM in Tamil Nadu in PIM - Paradigm for the $21^{\text {st }}$ century. Ed. L.K. Joshi and Rakesh Hooja, Rawat Publications, New Delhi.

[6] Government of Tamil Nadu, (2000). TNFMIS Act, Chennai: Government of Tamil Nadu.

[7] Gulati, Ashok, Ruth, S. Meinzen-Dick, and K. V. Raju. (2005). Institutional Reforms in Indian Irrigation, Edition-I, New Delhi: Sage Publications Pvt. Ltd.

[8] Hoojah \& Rakesh. (2006). Management of water for Agriculture. Jaipur: Rawat Publications.

[9] Kulkarni, S. (2011). Women and Decentralized water Governance: Issues, Challenges and the way forward. Economic and Political Weekly, 46 (18), 64-72.

[10] Pant Niranjan. (2008). Some Issues in Participatory Irrigation Management.Economic and Political Weekly, 43 (1), 30.

[11] Prakash, A, \& Sama, R. K. (2006). Social undercurrents in a waterscarce village. Economic and Political Weekly, 577-579.

[12] Shah, T. (1993). Groundwater markets and irrigation development. Oxford University Press. 